\title{
高分子系複合材料の制振特性のマイクロメカニックス解析*
}

\author{
荒 木 栄 敏*1, 山下 浩 儀*2 \\ 水谷直 弘*3, 杉 本 明 男*4
}

\section{Micromechanical Analysis of Vibration Damping Properties of A Polymer Based Composite Material}

\author{
Shigetoshi ARAKI*5, Hironori YAMASHITA, \\ Naohiro MIZUTANI and Akio SUGIMOTO \\ ${ }^{* 5}$ Department of Mechanical and System Engineering, Kyoto Institute of Technology, \\ Matsugasaki, Sakyo-ku, Kyoto-shi, Kyoto, 606-8585 Japan
}

\begin{abstract}
A tangent delta of a polymeric material, which influences the vibration damping capacity strongle, is high in value nearby the glass transition temperature of the material. Therefore, when the constituents of a polymer-based composite material are various in their glass transition temperatures, the magnitude of the macroscopic tangent delta of such a composite is expected to be high in wider range in temperature. In the present study, a shape memory polymer (SMP) particle/SMP matrix is used as a sample material and its macroscopic complex modulus and tangent delta are derived explicitly by using the equivalent inclusion method and the Mori-Tanaka's theorem. For the case of a four mode type of distribution of the glass transition temperatures of particles, the value of the macroscopic tangent delta becomes higher than that of the monolithic SMP at any temperature and it becomes constant in the temperature range from $20^{\circ} \mathrm{C}$ to $60^{\circ} \mathrm{C}$.
\end{abstract}

Key Words : Equivalent Inclusion Method, Tangent Delta, Shape Memory Polymer, Glass Transition Temperature, Polymer Based Composite

\section{1. 緒言}

高分子材料の制振特性を支配するタンジェントデル タはガラス転移点近傍において大きく増加するという 性質がある。この性質を利用して, ガラス転移点が異 なる材料を複合化することで広い温度範囲で制振特性 に優れた材料が創製できるといわれている. タンジェ ントデルタは複素弾性率の実部と虚部の比(1)である ことから,このような材料を創製するには, 構成要素 の複素弾性率や形状, 含有率等を含む形で複合材料全 体の巨視的な複素弾性率を求めることが必要となる.

複合材料の巨視的な力学特性を解析する有力な手法 の一つであるマイクロメカニックス (2) は, 材料中の強 化基材の形状や含有量などを陽に含む解が得られると いう特徴を有するものであり, 複合材料の弾性特性, 特に, 巨視的弾性係数に関する研究は枚挙にいとまが

* 原稿受付 2003 年 9 月 11 日.

*1 正員, 京都工芸瀻維大学工芸学部 (-606-8585 京都市左京 区松ヶ崎御所海道町).

*2 正員, 京都工芸瀻維大学大学院 [現, 三菱電機(株)].

*3 京都大学大学院エネルギー科学研究科(-606-8501 京都市 左京区吉田本町).

*4 正員, (株) 神戸製鋼所 (严651-2271 神戸市西区高塚台 1-5 5).

E-mail : araki@mech.kit.ac.jp
ない(3) (10). しかしながら, 粘弾性特性についてはわ ずかに Tayaらの空孔成長モデルの解析(1) などが行 われているだけで, 制振特性に関するものは著者の知 る限りほとんど行われていないようである.

線形粘弾性体における応力ーひずみ関係式は, 通常, 線形常微分方程式で表されるため, 定常振動入力に対 する定常応答の範囲であれば, 結局, 代数方程式に帰 着することになり, 形式的に線形弾性のものと一致す る(1). したがって, 複合材料の巨視的弾性係数の解に 含まれる構成要素の弾性定数を複素弾性率で置換える ことによって巨視的な複素弾性率を求めることができ る. 本研究は, このような手法を用いて, ガラス転移 点がー30〜 $70^{\circ} \mathrm{C}$ 範囲で比較的自由に設定できるとい う特徵を有するポリウレタン系の形状記憶ポリマ $(\mathrm{SMP})^{(12)(13)}$ から成る複合材料を取り上げ, 種々のガ ラス転移点を有するポリマ粒子が母材中に多数存在す る状態をモデル化し，モデルの制振特性が温度によっ てどのように変化するかを明らかにする。これによっ て, 広い温度範囲で良好な制振特性を示す高分子系複 合材料開発の可能性を探ることを目的とする.

\section{2. 線形粘弾性体の力学挙動}

\section{$2 \cdot 1 \quad$ 線形粘弾性体の複素弾性率(1)}

線形粘弾性 
体に, 振幅 $\sigma_{0}$, 角振動数 $\omega$ の振動応力,

$$
\sigma^{c}(t)=\sigma_{0} \exp (i \omega t)
$$

が作用し，十分時間 $t$ が経過して定常応答している状 態を想定する。ここで上付添字 $c$ は複素量を表し,$i$ $=\sqrt{-1}$ である。このとき，定常ひずみ応答 $\varepsilon^{c}(t)$ は， 複素コンプライアンス $D^{c}(\omega)$ を用いて,

$$
\varepsilon^{c}(t)=D^{c}(\omega) \sigma^{c}(t)
$$

となる。また,ひずみ入力 $\varepsilon^{c}(t)=\varepsilon_{0} \exp (i \omega t)$ に対す る応力応答 $\sigma^{c}(t)$ は, 複素弾性率 $E^{c}(\omega)$ を用いて,

$$
\sigma^{c}(t)=E^{c}(\omega) \varepsilon^{c}(t)
$$

で与えられる。 $E^{c}(\omega)$ と $D^{c}(\omega)$ との間には, $E^{c}(\omega)$ • $D^{c}(\omega)=1$ なる関係が成立する。また, 複素量の実部 と虚部を上付添字'と”を用いて区分すると, 複素弾 性係数は $E^{c}(\omega)=E^{\prime}(\omega)+i E^{\prime \prime}(\omega)$, 複素コンプライア ンスは $D^{c}(\omega)=D^{\prime}(\omega)-i D^{\prime \prime}(\omega)$ となる。このとき，夕 ンジェントデルタ $\tan \delta$ は,

$$
\tan \delta=\frac{E^{\prime \prime}(\omega)}{E^{\prime}(\omega)}=\frac{D^{\prime \prime}(\omega)}{D^{\prime}(\omega)}
$$

で定義され，これを用いて式(2)を書換えると，

$\varepsilon(t)=D^{\prime}(\omega) \sigma_{0}\{\cos \omega t+\tan \delta \cdot \sin \omega t\} \cdots \cdots(5)$ となる.式(5)より, $\tan \delta=0$ のときには $\varepsilon(t)=$ $D^{\prime}(\omega) \sigma(t)$ となるため, $D^{\prime}(\omega)$ は線形弾性問題におけ る弾性コンプライアンスに相当することがわかる．次 に, 1 周期の間になされる単位体積当たりの損失仕事 $W_{\sigma}$ を求める。式( 1 )，（5) と式(4)より,

$$
W_{\sigma}=\int_{0}^{2 \pi / \omega} \sigma(t) d \varepsilon(t)=\pi \sigma_{0}^{2} D^{\prime \prime}(\omega) \cdots \cdots \cdots(6 \cdot \mathrm{a})
$$

となる，また，同様にしてひずみ入力の場合の損失仕 事 $W_{\varepsilon}$ は,

$$
W_{\varepsilon}=\pi \varepsilon_{0}^{2} E^{\prime \prime}(\omega)
$$

となる。したがって, $E^{\prime \prime}(\omega)$ と $D^{\prime \prime}(\omega)$ は損失仕事を 表すことがわかる.

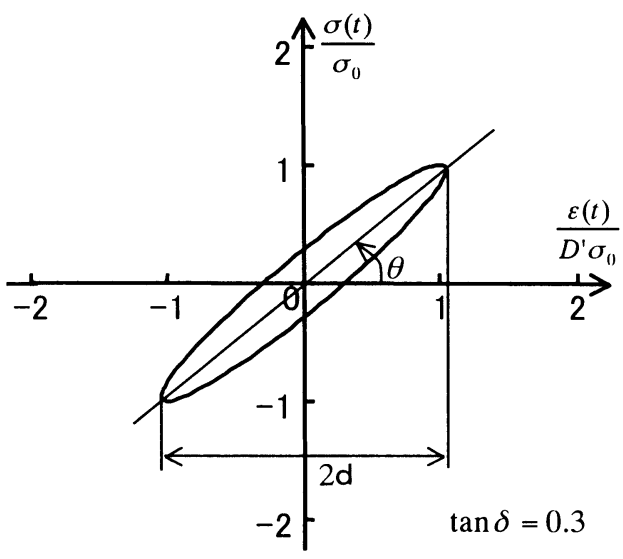

Fig. 1 Hysteresis loop to sine wave excitation
$2 \cdot 2$ 線形粘弾性体のヒステリシスループ 式 (1) と式 (5)より $\sin \omega t$ と $\cos \omega t$ とを消去すると,

$$
\frac{\varepsilon(t)}{D^{\prime} \sigma_{0}}=\frac{\sigma(t)}{\sigma_{0}} \pm \tan \delta \sqrt{1-\left\{\frac{\sigma(t)}{\sigma_{0}}\right\}^{2}} \text {. }
$$

となる，同様にして，ひずみ入力の場合には，

$$
\frac{\sigma(t)}{E^{\prime} \varepsilon_{0}}=\frac{\varepsilon(t)}{\varepsilon_{0}} \pm \tan \delta \sqrt{1-\left\{\frac{\varepsilon(t)}{\varepsilon_{0}}\right\}^{2}} \cdots
$$

となる。図 1 に, 式 $(7 \cdot \mathrm{a})$ を用いて求めた $\sigma(t) / \sigma_{0}$ と $\varepsilon(t) /\left(D^{\prime} \sigma_{0}\right)$ の関係を示す. 図中のだ円の面積を $S$, アスペクト比を $k$, 傾き角を $\theta$, 応答振幅を $d$ とおく と,これらはそれぞれ，

$S=\pi \tan \delta$

$k=\frac{2 \tan \delta}{\left(2+\tan ^{2} \delta\right)-\sqrt{4+\tan ^{4} \delta}}$

$$
\begin{aligned}
& \theta=\frac{1}{2} \tan ^{-1}\left(\frac{2}{\tan ^{2} \delta}\right) \cdots \cdots \cdots \cdots \cdots \cdots \cdots \cdots \cdots \cdot(8 \cdot \mathrm{c}) \\
& d=\sqrt{1+\tan ^{2} \delta}
\end{aligned}
$$

となる.したがって，この粘弾性体の制振特性を表す

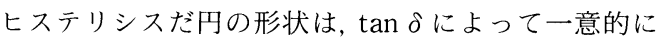
表されることがわかる. また，式（4)の関係から，式 $(6 \cdot \mathrm{a})$ の損失仕事 $W_{\sigma}$ はこのだ円で囲まれる領域の仕 事を表していることがわかる。

$2 \cdot 3$ 線形粘弾性体の等価式 線形粘弾性体の構 成式は，粘弾性体に生じる応力とひずみをそれぞれ $\sigma(t), \varepsilon(t)$ とおくと, 一次元の場合には一般的に,

$$
P(D) \sigma(t)=Q(D) \varepsilon(t)
$$

と書くことができる.ここで $D \equiv \partial / \partial t て ゙ あ り ，$

$$
\begin{aligned}
& P(D)=\sum_{k=0}^{m} a_{k} D^{k}=\sum_{k=0}^{m} a_{k} \frac{\partial^{k}}{\partial t^{k}} \\
& Q(D)=\sum_{k=0}^{n} b_{k} D^{k}=\sum_{k=0}^{n} b_{k} \frac{\partial^{k}}{\partial t^{k}}
\end{aligned}
$$

である、いま，このような構成関係を有する無限体 $D$ 中のだ円体部分領域 $\Omega$ 内に, 振幅 $\bar{\varepsilon}_{i j}^{*}$ を有する固有ひ ずみ,

$$
\varepsilon_{i j}^{*}(t)=\bar{\varepsilon}_{i j}^{*} \exp (i \omega t)
$$

が存在する場合，この介在物領域 $\Omega$ 内の応力 $\sigma_{i j}-$ ひ ずみ $\varepsilon_{i j}$ 関係式は,

$$
\begin{aligned}
& P_{1}(D) \sigma_{i j}^{\prime}(t)=Q_{1}(D)\left\{\varepsilon_{i j}^{\prime}(t)-\varepsilon_{i j}^{* \prime}(t)\right\} \cdots \cdots(12 \cdot \mathrm{a}) \\
& P_{2}(D) \sigma_{k k}(t)=Q_{2}(D)\left\{\varepsilon_{k k}(t)-\varepsilon_{k k}^{*}(t)\right\} \\
& \cdots(12 \cdot \mathrm{b})
\end{aligned}
$$

となる。ここで $P_{i}(D), Q_{i}(D)$ は, 式 $(10)$ と同様に $D$ $\equiv \partial / \partial t$ の関数である. また，上付添字”は偏差成分を 表す. 次に，母材とは異なる線形粘弾性特性 $P_{i}^{*}(D)$, $Q_{i}^{*}(D)$ を有する不均質物 $\Omega$ が含まれる状態を考え る、このとき， $\Omega$ 内の応力ーひずみ関係式は,

$$
\begin{aligned}
& P_{1}^{*}(D) \sigma_{i j}^{\prime}(t)=Q_{1}^{*}(D) \varepsilon_{i j}^{\prime}(t) \cdots \cdots \cdots \cdots \cdots \cdots(13 \cdot \mathrm{a}) \\
& P_{2}^{*}(D) \sigma_{k k}(t)=Q_{2}^{*}(D) \varepsilon_{k k}(t) \cdots \cdots \cdots \cdots \cdots(13 \cdot \mathrm{b})
\end{aligned}
$$

となる.式(12)と式(13)を等置し, $\exp (i \omega t)$ で両辺 
を除すと, 線形粘弾性不均質物 $\Omega$ の等価式は,

$$
\begin{aligned}
& \frac{Q_{1}^{*}(i \omega)}{P_{i}^{*}(i \omega)}\left(\bar{\varepsilon}_{i j}^{0 ;}+\bar{\varepsilon}_{i j}^{\prime}\right)=\frac{Q_{1}(i \omega)}{P_{1}(i \omega)}\left(\bar{\varepsilon}_{i j}^{0 \prime}+\bar{\varepsilon}_{i j}^{\prime}-\bar{\varepsilon}_{i j}^{* \prime}\right) \\
& \ldots \ldots \ldots \ldots \ldots(14 \cdot \mathrm{a}) \\
& \frac{Q_{2}^{*}(i \omega)}{P_{2}^{*}(i \omega)}\left(\bar{\varepsilon}_{k k}^{0}+\bar{\varepsilon}_{k k}\right)=\frac{Q_{2}(i \omega)}{P_{2}(i \omega)}\left(\bar{\varepsilon}_{k k}^{0}+\bar{\varepsilon}_{k k}-\bar{\varepsilon}_{k k}^{*}\right)
\end{aligned}
$$

となる.ここで $\bar{\varepsilon}_{2 j}^{0+}$ などの上線の付いたものはそれぞ れの振幅を表す。

一方, 線形弾性不均質物の等価式は,

$$
\begin{aligned}
& 2 \mu^{*}\left(\bar{\varepsilon}_{i j}^{0 \prime}+\bar{\varepsilon}_{i j}^{\prime}\right)=2 \mu\left(\bar{\varepsilon}_{i j}^{0 \prime}+\bar{\varepsilon}_{i j}^{\prime}-\bar{\varepsilon}_{i j}^{* \prime}\right) \cdots \cdots \cdots(15 \cdot \mathrm{a}) \\
& 3 K^{*}\left(\bar{\varepsilon}_{k k}^{0}+\bar{\varepsilon}_{k k}\right)=3 K\left(\bar{\varepsilon}_{k k}^{0}+\bar{\varepsilon}_{k k}-\bar{\varepsilon}_{k k}^{*}\right) \cdots(15 \cdot \mathrm{b})
\end{aligned}
$$

となる(2).ここで, $\mu$ と $K$ は母材の剛性率と体積弾 性係数, $\mu^{*}$ と $K^{*}$ は不均質物の剛性率と体積弾性係 数である.また, Eshelby の解より $\bar{\varepsilon}_{i j}$ は,

$$
\bar{\varepsilon}_{i j}=S_{i j k l} \bar{\varepsilon}_{k l}^{*}
$$

で与えられる。ここで $S_{i j k l}$ は不均質物の Eshelby テ ンソル(2) である.

式(14) と式(15)を比較すると,

$$
\begin{aligned}
& 2 \mu^{*}=\frac{Q_{1}^{*}(i \omega)}{P_{1}^{*}(i \omega)}, 2 \mu=\frac{Q_{1}(i \omega)}{P_{1}(i \omega)} \\
& 3 K^{*}=\frac{Q_{2}^{*}(i \omega)}{P_{2}^{*}(i \omega)}, 3 K=\frac{Q_{2}(i \omega)}{P_{2}(i \omega)}
\end{aligned}
$$

なる対応関係が成り立つ。これらの結果より, 線形粘 弾性体の等価式は線形弾性体に対する等価式の弾性係 数を複素量に置換えたものとなることがわかる。した がって, 線形粘弾性体からなる複合材料の巨視的複素 弾性率を求めるには，これに対応する線形弾性体から なる複合材料の巨視的弾性係数を求め, それに含まれ る構成要素の弾性定数を複素弾性率で置換えればよい ことがわかる.このような手順を用いて以下の解析を 進めることにする。

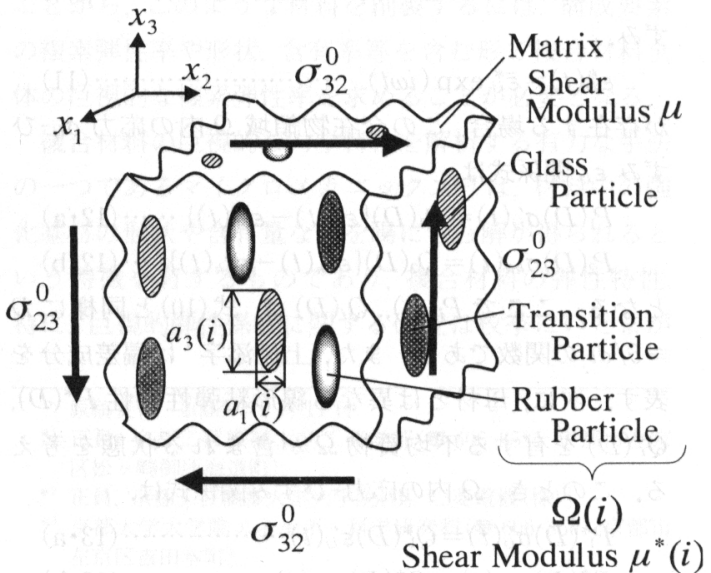

Fig. 2 Elastic model for a SMP Particle reinforced SMP Composite

\section{3. 高分子系複合材料のモデル化と解析}

$3 \cdot 1$ 幾何学的モデル化 高分子系複合材料のモ デルとしては, $-30 \sim 70^{\circ} \mathrm{C}$ の間でガラス転移点が比較 的自由に設定できるという特幑を有するポリウレタン 系の形状記憶ポリマ $(\mathrm{SMP})^{(12)(13)}$ からなる複合材料を 想定する. 図 2 は SMP 母材 $D$ 中に種々のガラス転 移点を有する SMP 粒子が完全にランダムに存在する 状態を示したものであり, そのガラス転移点の值によ って,ガラス状態, ゴム状態およびそれらの中間の遷 移状態にある粒子が混在している。これらの粒子はそ のガラス転移点によって区別され, 各領域を $\Omega(i)$ と 表すことにする。また，すべての SMP 粒子の長手方 向は図の $x_{3}$ 軸方向に一致し, $x_{1}-x_{2}$ 面内で対称な回転 だ円体形状とする。すなわち， $i$ 番めの粒子に対して， 長径を $a_{3}(i)$, 短径を $a_{1}(i)$ とすると,

$$
\left\{\frac{x_{1}}{a_{1}(i)}\right\}^{2}+\left\{\frac{x_{2}}{a_{1}(i)}\right\}^{2}+\left\{\frac{x_{3}}{a_{3}(i)}\right\}^{2} \leq 1 \text {. }
$$

なる形状とする. 粒子の Eshelby テンソルは, その大 きさではなくアスペクト比に依存するため, $x_{1}-x_{2}$ 面 内の短径に対する $x_{3}$ 方向の長径の比をアスペクト比 $\omega(i)=a_{3}(i) / a_{1}(i)$ と定める. また, $D$ には作用せん断 応力 $\sigma_{23}^{0}$ と $\sigma_{32}^{0}$ が作用するものとする。

\section{$3 \cdot 2$ 巨視的剛性率の解析}

$3 \cdot 2 \cdot 1$ 粒子の等価固有ひずみ 粒子の等価式は, $\Omega(i)$ 内で,

$$
\begin{aligned}
\sigma_{i j}^{0} & +\tilde{\sigma}_{i j}+\sigma_{i j}^{\infty}(i) \\
& =C_{i j k l}^{*}(i)\left\{\varepsilon_{k l}^{0}+\tilde{\varepsilon}_{k l}+S_{k l m n}(i) \varepsilon_{m n}^{*}(i)\right\} \\
& =C_{i j k l}\left\{\varepsilon_{k l}^{0}+\tilde{\varepsilon}_{k l}+S_{k l m n}(i) \varepsilon_{m n}^{*}(i)-\varepsilon_{k l}^{*}(i)\right\}
\end{aligned}
$$

となる。ここで $C_{i j k l}$ と $C_{i j k l}^{*}(i)$ は，それぞれ母材と $\Omega(i)$ 粒子の弾性定数であり, $S_{i j k l}(i)$ は $\Omega(i)$ の Eshelby テンソルである. また, $\varepsilon_{i j}^{*}(i)$ は母材と $\Omega(i)$ の弾性定数の違いを代行する等価固有ひずみ, $\sigma_{i j}^{\infty}(i)$ は固有応力である。 $\sigma_{i j}^{0}$ と $\varepsilon_{i j}^{0}$ は作用応力と作用ひず み, $\tilde{\sigma}_{i j}$ と $\tilde{\varepsilon}_{i j}$ は相互作用場であり,これらの間に,

$$
\sigma_{i j}^{0}=G_{i j k l} \varepsilon_{k l}^{0} l, \tilde{\sigma}_{i j}=C_{i j k l} \tilde{\varepsilon}_{k l}
$$

なる関係がある。

等価式(19)をせん断成分についてのみ書き直し，作 用応力の対称性 $\sigma_{23}^{0}=\sigma_{32}^{0}$ と固有ひずみの対称条件 $\varepsilon_{23}^{*}$ $(i)=\varepsilon_{32}^{*}(i)$ を用いると,

$$
\begin{aligned}
& 2 \mu^{*}(i)\left\{\varepsilon_{23}^{0}+\tilde{\varepsilon}_{23}+2 S_{2323}(i) \varepsilon_{23}^{*}(i)\right\} \\
& \quad=2 \mu\left\{\varepsilon_{23}^{0}+\tilde{\varepsilon}_{23}+2 S_{2323}(i) \varepsilon_{23}^{*}(i)-\varepsilon_{23}^{*}(i)\right\}
\end{aligned}
$$

となる。ここで $\mu$ と $\mu^{*}(i)$ は材と $\Omega(i)$ の剛性率で ある。また, Eshelbyテンソル $S_{2323}(i)$ は, だ円体 $\Omega($ i)の形状にかかわらず, 


$$
S_{2323}(i)=\frac{(1-\nu)-(1+\nu) H_{3}^{s}(i)+2 H_{31}^{s}(i)}{4(1-\nu)}
$$

となる(14).ここで, レは母材のポアソン比であり, $H_{3}^{s}(i)$ と $H_{31}^{s}(i)$ は, 著者らが求めた回転だ円体に対す る Eshelby テンソルの形状因子(14)である. 式(22)を 等価式(21)に代入すると, 等価固有ひずみ $\varepsilon_{23}^{*}(i)$ は,

$$
\varepsilon_{23}^{*}(i)=-A(i)\left(\varepsilon_{23}^{0}+\tilde{\varepsilon}_{23}\right)
$$

となる.ここで,

$$
\begin{aligned}
& A(i)=\frac{g(i)-1}{2\{g(i)-1\} S_{2323}(i)+1} \cdots \cdots \cdots \cdots(24 \cdot \mathrm{a}) \\
& g(i)=\frac{\mu^{*}(i)}{\mu}
\end{aligned}
$$

である.また, 式 (19)と式 $(20) よ り$ 固有応力 $\sigma_{i j}^{\infty}(i)$ は 次式となる。

$$
\sigma_{i j}^{\infty}(i)=C_{i j k l}\left\{S_{k l m n}(i) \varepsilon_{m n}^{*}(i)-\varepsilon_{k l}^{*}(i)\right\}
$$

$3 \cdot 2 \cdot 2$ 相互作用ひずみ 相互作用応力 $\tilde{\sigma}_{i j}$ は, $\Omega(i)$ の体積含有率を $f(i)$ とおくと, Mori-Tanaka の定理(15)より,

$$
\tilde{\sigma}_{i j}=-\sum_{i} f(i) \sigma_{i j}^{\infty}(i)
$$

となる。相互作用ひずみ $\tilde{\varepsilon}_{23}$ は, 式(20)に式(26)を代 入し，対称性を用いることによって，

$$
\tilde{\varepsilon}_{23}=-\sum_{i} f(i) B(i) \varepsilon_{23}^{*}(i)
$$

となる、ここで,

$$
B(i)=2 S_{2323}(i)-1
$$

である.式(27)に式(23)を代入し， $\varepsilon_{23}^{0}$ と $\tilde{\varepsilon}_{23}$ が $D$ 内 で一様であることを考慮すると，

$$
\begin{aligned}
& \tilde{\varepsilon}_{23}=\left(\varepsilon_{23}^{0}+\tilde{\varepsilon}_{23}\right) \sum_{i} f(i) A(i) B(i) \\
& \therefore \quad \tilde{\varepsilon}_{23}=\frac{\sum_{i} f(i) A(i) B(i)}{1-\sum_{i} f(i) A(i) B(i)} \varepsilon_{23}^{0}
\end{aligned}
$$

を得る。式(29)を式(23)に代入すると, 最終的に等価

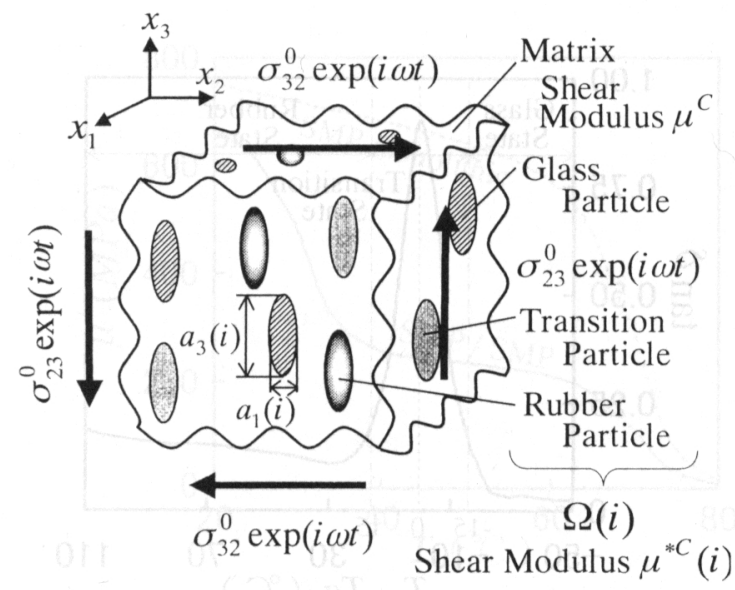

Fig. 3 Viscoelastic model for a SMP Particle reinforced SMP Composite
固有ひずみは次式となる。

$$
\varepsilon_{23}^{*}(i)=-\frac{A(i)}{1-\sum_{i} f(i) A(i) B(i)} \varepsilon_{23}^{0}
$$

$3 \cdot 2 \cdot 3$ 巨視的剛性率 物体 $D$ 内に生じる巨視的 平均ひずみ $\bar{\varepsilon}_{i j}$ は,

$$
\bar{\varepsilon}_{i j}=\varepsilon_{i j}^{0}+\sum_{i} f(i) \varepsilon_{i j}^{*}(i)
$$

となる(14).これに式 $(30)$ を代入すると，

$$
\bar{\varepsilon}_{23}=\frac{1-\sum_{i} f(i) A(i)\{B(i)+1\}}{1-\sum_{i} f(i) A(i) B(i)} \varepsilon_{23}^{0} \ldots
$$

を得る。巨視的剛性率公は,

$$
\bar{\mu}=\frac{\sigma_{23}^{0}}{2 \bar{\varepsilon}_{23}}=\frac{\varepsilon_{23}^{0}}{\bar{\varepsilon}_{23}} \mu
$$

により求められるため, 式(33)に式(32)を代入する と,

$$
\bar{\mu}=\frac{1-\sum_{i} f(i) A(i) B(i)}{1-\sum_{i} f(i) A(i)\{B(i)+1\}} \mu
$$

を得る。

$3 \cdot 3$ 高分子系複合材料の巨視的タンジェントデル タの解析 図 3 は図 2 の弾性モデルに対応する線形 粘弾性モデルである.母材と $\Omega(i)$ 粒子の複素弾性率 を $C_{i j k l}^{c}$ と $C_{i j k l}^{* c}(i)$ とし, $D$ には振動せん断応力 $\sigma_{23}^{0}$ $\exp (i \omega t)$ と $\sigma_{32}^{0} \exp (i \omega t)$ が作用している.

このモデルの巨視的複素弾性率を求めるために, 2 章で述べた方法に従って弾性問題における巨視的剛性 率を複素量に変換する。このために, まず, 弾性解析 で用いた弾性定数を次のような複素量に置換える.

$$
\begin{aligned}
& \mu \rightarrow \mu^{c}=\mu^{\prime}+i \mu^{\prime \prime}=\mu^{\prime}(1+i \tan \delta) \\
& \mu^{*}(i) \rightarrow \mu^{* c}(i)=\mu^{* \prime}(i)+i \mu^{* \prime \prime}(i) \\
& =\mu^{* \prime}(i)\left\{1+i \tan \delta^{*}(i)\right\} \\
& \nu \rightarrow \nu^{c}=\nu^{\prime}+i \nu^{\prime \prime}
\end{aligned}
$$

ここで $\tan \delta と \tan \delta^{*}(i)$ は, それぞれ母材と粒子 $\Omega(i)$ のタジェントデルタである. 次に, Eshelby テ ンソルと $g(i)$ に対して,

$$
\begin{aligned}
& S_{2323}(i) \rightarrow S_{2323}^{c}(i)=S_{2323}^{\prime}(i)+i S_{2323}^{\prime \prime}(i) \cdots(36 \bullet \mathrm{a}) \\
& g(i) \rightarrow g^{c}(i)=g^{\prime}(i)+i g^{\prime \prime}(i) \cdots \cdots \cdots \cdots \cdots \cdots(36 \bullet \mathrm{b})
\end{aligned}
$$

なる置換えを行う. 式 (22)と式 $(24 \cdot b)$ に対して, 式 (35) の置換えを行うとともに, 式(36)に従ってその結 果を整理すると,

$$
\begin{aligned}
& S_{2323}^{\prime}(i)=\frac{1}{4}+\frac{\left(\nu^{\prime 2}+\nu^{\prime \prime 2}-1\right) H_{3}^{s}(i)+2\left(1-\nu^{\prime}\right) H_{31}^{s}(i)}{4\left\{\left(1-\nu^{\prime}\right)^{2}+\nu^{\prime \prime 2}\right\}} \\
& \cdots \cdots \cdots \cdots(37 \cdot \mathrm{a}) \\
& S_{2323}^{\prime \prime}(i)=\frac{\nu^{\prime \prime}\left\{H_{31}^{s}(i)-H_{3}^{s}(i)\right\}}{2\left\{\left(1-\nu^{\prime}\right)^{2}+\nu^{\prime \prime 2}\right\}} \cdots \cdots \cdots \cdots(37 \cdot \mathrm{b}) \\
& g^{\prime}(i)=\frac{\mu^{* \prime}(i)}{\mu^{\prime}} \cdot \frac{1}{1+\tan ^{2} \delta}\left\{1+\tan \delta \tan \delta^{*}(i)\right\}
\end{aligned}
$$


$g^{\prime \prime}(i)=\frac{\mu^{* \prime}(i)}{\mu^{\prime}} \cdot \frac{1}{1+\tan ^{2} \delta}\left\{\tan \delta^{*}(i)-\tan \delta\right\}$

となる。 さらに, 式 $(24 \cdot a)$ と式(28)についても,

$$
\begin{aligned}
& A(i) \rightarrow A^{c}(i)=A^{\prime}(i)+i A^{\prime \prime}(i) \\
& B(i) \rightarrow B^{c}(i)=B^{\prime}(i)+i B^{\prime \prime}(i)
\end{aligned}
$$

なる置換えを行うと, 式(37)より，

$$
\begin{aligned}
& A^{\prime}(i)=\frac{\left\{g^{\prime}(i)-1\right\} A_{1}(i)+g^{\prime \prime}(i) A_{2}(i)}{A_{1}(i)^{2}+A_{2}(i)^{2}} \cdots(39 \cdot \mathrm{a}) \\
& A^{\prime \prime}(i)=\frac{g^{\prime \prime}(i) A_{1}(i)-\left\{g^{\prime}(i)-1\right\} A_{2}(i)}{A_{1}(i)^{2}+A_{2}(i)^{2}} \cdots(39 \cdot \mathrm{b}) \\
& B^{\prime}(i)=2 S_{2323}^{\prime}(i)-1, B^{\prime \prime}(i)=2 S_{2323}^{\prime \prime}(i) \cdots(39 \cdot \mathrm{c})
\end{aligned}
$$

となる。ここで式中の係数 $A_{1}(i)$ と $A_{2}(i)$ は以下のと おりである。

$$
\begin{array}{r}
A_{1}(i)=2\left\{g^{\prime}(i)-1\right\} S_{2323}^{\prime}(i)+1-2 g^{\prime \prime}(i) S_{2323}^{\prime \prime}(i) \\
\cdots \cdots \cdots \cdots \cdot(40 \cdot a) \\
A_{2}(i)=2\left\{g^{\prime}(i)-1\right\} S_{2323}^{\prime \prime}(i)+2 g^{\prime \prime}(i) S_{2323}^{\prime}(i)
\end{array}
$$

これらの結果を用いて, 式(34)の $\bar{\mu} に$ 対して式(35) の置換えを行うと, 巨視的複素剛性率は,

$$
\begin{aligned}
\bar{\mu}^{c} & =\frac{1-\sum_{i} f(i) A^{c}(i) B^{c}(i)}{1-\sum_{i} f(i) A^{c}(i)\left\{B^{c}(i)+1\right\}} \mu^{c} \\
& =\left(F^{\prime}+i F^{\prime \prime}\right)\left(\mu^{\prime}+i \mu^{\prime \prime}\right) \\
& =\mu^{\prime}\left\{\left(F^{\prime}-F^{\prime \prime} \tan \delta\right)+i\left(F^{\prime} \tan \delta+F^{\prime \prime}\right)\right\}
\end{aligned}
$$

となる.各係数は以下のとおりである.

$$
\begin{aligned}
& F^{\prime}=\frac{\left(1-G_{1}\right)\left(1-G_{3}\right)+G_{2} G_{4}}{\left(1-G_{3}\right)^{2}+G_{4}^{2}} \cdots \cdots \cdots \cdots(42 \cdot \mathrm{a}) \\
& F^{\prime \prime}=\frac{\left(1-G_{1}\right) G_{4}-G_{2}\left(1-G_{3}\right)}{\left(1-G_{3}\right)^{2}+G_{4}^{2}} \cdots \cdots \cdots \cdots \cdots(42 \cdot \mathrm{b}) \\
& G_{k}=\sum_{i} G_{k}(i) \quad(k=1,2,3,4) \cdots \cdots \cdots \cdots \cdots(42 \cdot \mathrm{c}) \\
& G_{1}(i)=f(i)\left\{A^{\prime}(i) B^{\prime}(i)-A^{\prime \prime}(i) B^{\prime \prime}(i)\right\} \cdots(42 \cdot \mathrm{d})
\end{aligned}
$$

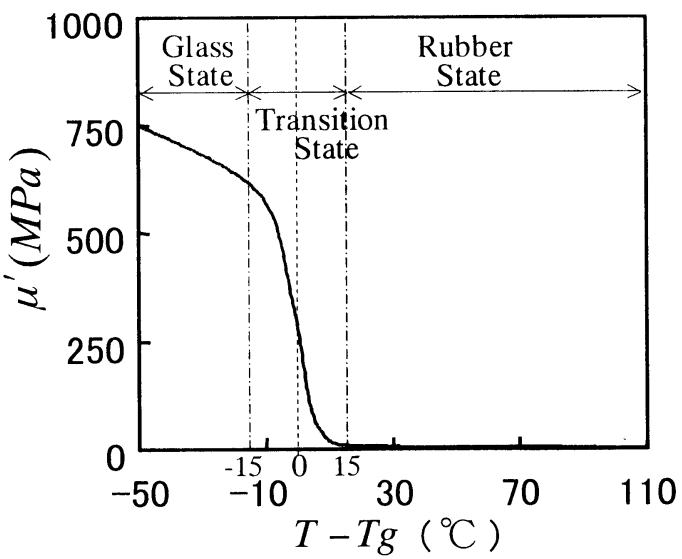

Fig. 4 Shear modulus of SMP

$$
\begin{aligned}
& G_{2}(i)=f(i)\left\{A^{\prime}(i) B^{\prime \prime}(i)+A^{\prime \prime}(i) B^{\prime}(i)\right\} \cdots(42 \cdot \mathrm{e}) \\
& G_{3}(i)=f(i)\left[A^{\prime}(i)\left\{B^{\prime}(i)+1\right\}-A^{\prime \prime}(i) B^{\prime \prime}(i)\right]
\end{aligned}
$$

$G_{4}(i)=f(i)\left[A^{\prime}(i) B^{\prime \prime}(i)+A^{\prime \prime}(i)\left\{B^{\prime}(i)+1\right\}\right]$

巨視的剛性率 $\bar{\mu}^{c} を, \bar{\mu}^{c}=\bar{\mu}^{\prime}+i \bar{\mu}^{\prime \prime}$ で表すと, 式(41) から，

$$
\begin{aligned}
& \bar{\mu}^{\prime}=\mu^{\prime}\left(F^{\prime}-F^{\prime \prime} \tan \delta\right) \\
& \cdot(43 \cdot a) \\
& \bar{\mu}^{\prime \prime}=\mu^{\prime}\left(F^{\prime} \tan \delta+F^{\prime \prime}\right)
\end{aligned}
$$

となる。さらに、これらの比を取ることにより，巨視 的タンジェントデルタ $\tan \delta$ は次式となる。

$$
\tan \bar{\delta}=\frac{\bar{\mu}^{\prime \prime}}{\bar{\mu}^{\prime}}=\frac{F^{\prime} \tan \delta+F^{\prime \prime}}{F^{\prime}-F^{\prime \prime} \tan \delta}
$$

\section{4. 数值計算結果および考察}

$4 \cdot 1$ モデルの材料定数 本解析では母材, 粒子 ともにポリウレタン系形状記憶ポリマ(SMP)を用い た. SMP の剛性率 $\mu^{\prime}$ とタンジェントデルタの温度変 化については，戸伏らの実験結果(16)を用いた。これ らをそれぞれ図 4 と図 5 に示す。ポアソン比の実部 レ'の温度変化については既報で示したデー夕(17)を用 いた。これを図 6 に示す。なお，これらの図中にはガ ラス領域とゴム領域抢よび遷移領域の範囲を示してい るが，遷移領域の温度幅は既報と同様に $T_{g}$ を挟んで $\pm 15^{\circ} \mathrm{C}$ とた。また，虚部レ゙については零とおいた。 なお，母材のガラス転移点 $T_{g}$ は $70^{\circ} \mathrm{C} と し ，$ 粒子はす べて球形とした。

\section{$4 \cdot 2$ 巨視的剛性率とタンジェントデルタの解析}

$4 \cdot 2 \cdot 1$ 粒子のガラス転移点分布が単分散の場合 まず最初に, 粒子のガラス転移点がすべて同じであ る単分散の場合に対する解析結果を示す。

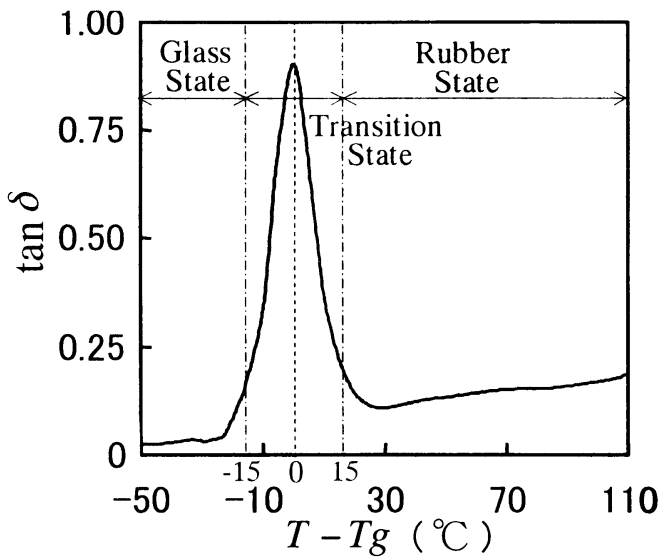

Fig. $5 \tan \hat{o}$ of SMP 
図 7 は, 粒子のガラス転移点が $30^{\circ} \mathrm{C}$, 体積含有率が $50 \%$ の場合に対する巨視的剛性率 $\bar{\mu}^{\prime}$ の温度変化を示 したものである、図中の実線が解析結果であり, 破線 は母材単体の場合の結果を示す. 図 7 より, 巨視的剛 性率 $\bar{\mu}^{\prime}$ は, 温度 $T$ が $30^{\circ} \mathrm{Cを}$ 超えると急激に低下し, $65^{\circ} \mathrm{C}$ までほぼ一定值を保った後に, $65^{\circ} \mathrm{Cを}$ 超えるとも う一度急激に低下寸る傾向にあることがわかる，最初 の $30^{\circ} \mathrm{C}$ 近傍における剛性率の低下は, 粒子のガラス転

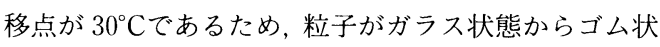
態へと遷移したことによって生じたものである。ま た, $35 \sim 65^{\circ} \mathrm{C}$ 温度範囲で一定值を示した理由は, こ の温度範囲では粒子はすでにゴム状態であり, ガラス 転移点が $70^{\circ} \mathrm{C}$ あるる材は依然としてガラス状態を 保っているためであると考えられる． $65^{\circ} \mathrm{Cを}$ 超えて再 度剛性が低下する原因は, 母材がゴム状態へと遷移し たことによるものである.したがって,この結果は材

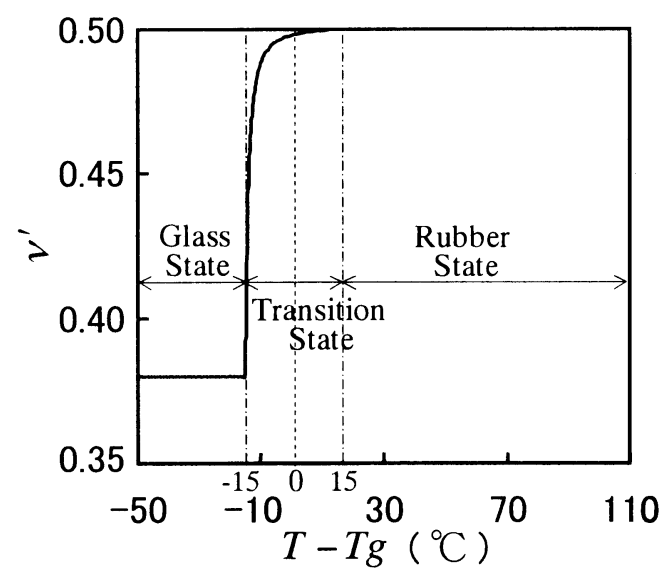

Fig. 6 Poissons' ratio of SMP

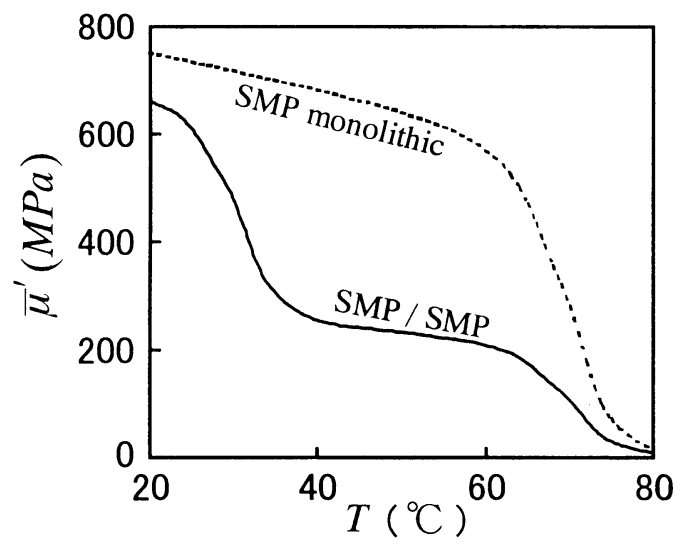

Fig. 7 Macroscopic shear modulus of the SMP Particle reinforced SMP Composite
料中の構成要素の状態変化を考えることによって説明 でき，極めて妥当な結果であるものと思われる．さら に, 母材単体においては, 温度増加につれて徐々に剛 性は低下し, $65^{\circ} \mathrm{Cを}$ 超えると急激にその值が減少して いることがわかる，両者を比較すると，低いがラス転 移点を有する粒子を含む複合材料のほうが明らかに巨 視的剛性率は低くなることがわかる. したがって, 剛 性率という観点からは, ガラス転移点が高い粒子を混 入すべきであると思われる。図 8 は, 図 7 に対応する 巨視的タンジェントデルタ $\tan \bar{\delta}$ の温度変化を示した ものである. 図中の実線が解析結果であり, 破線は母 材単体の結果である. 図 8 より, 複合材料の $\tan \bar{\delta}$ は, 温度上昇につれて増加し, $30^{\circ} \mathrm{C}$ 近傍でいったん大きく なった後, 逆に減少する傾向にあることがわかる.し かしながら, この後さらに温度を上昇させると再び増

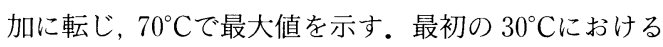

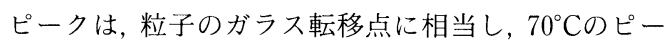
クは母材のそれに対応する. 破線で示される母材単体

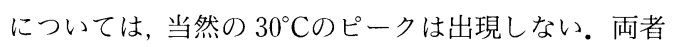
を比較すると, 複合材料の $\tan \bar{\delta}$ は, $20^{\circ} \mathrm{C}$ から約 $40^{\circ} \mathrm{C}$ までの温度範囲で母材単体のそれより大きくなってい ることがわかる. したがって, 低いがラス転移点を有 する粒子を混入させることで, 単体ではあり得ない温 度における $\tan \delta$ の増加が可能であることがわかっ た。

さらに, $70^{\circ} \mathrm{C} に お け る \tan \bar{\delta}$ の最大值は, 母材単体 のものとほとんど変わらないこともわかる. ガラス転

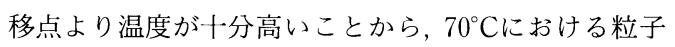
の $\tan \delta$ の值は小さくなり, $\tan \bar{\delta} に$ 対する寄与は小 さなものとなる.このため, $70^{\circ} \mathrm{Cにおける} \tan \bar{\delta}$ は,

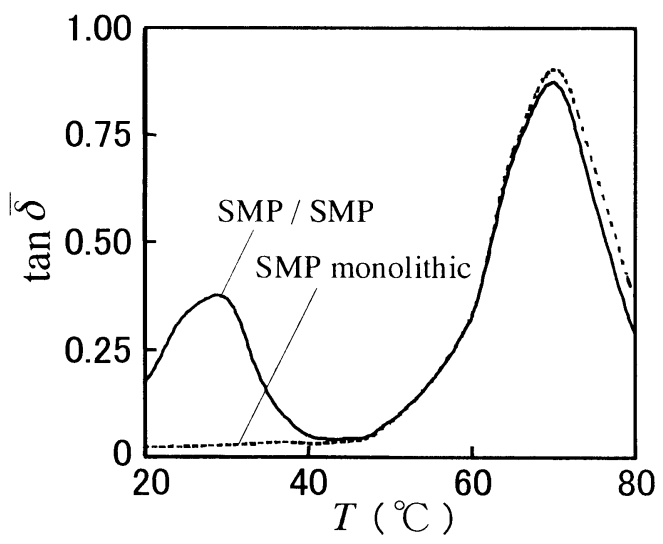

Fig. $8 \tan \bar{\delta}$ of the SMP Particle reinforced SMP Composite 
体積含有率 $50 \%$ の材の特性のみが発露したものと 考えられる。したがって，この点だけを考えると $\tan$ ঠは母材単体に比べて小さくなることになる.しかし ながら，これとは逆の効果も存在する。図 4 に示した ように, SMP の剛性率はガラス転移点を挟んで 2 け

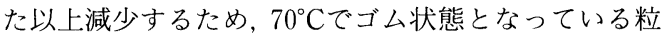
子は極めて低い剛性率を有することになる。この結果 として, 材料全体の剛性率 $\bar{\mu}^{\prime}$ は図 7 に示したように 低くなっている. 式 $(43 \cdot a)$ と式(44)より, $\tan \bar{\delta}$ の分 母が剛性率 $\bar{\mu}^{\prime}$ に対応するため, $\bar{\mu}^{\prime}$ が減少すると, 結 果的に $\tan \bar{\delta}$ は増加することになる.したがって, こ れら二つの効果が相殺しあって, 図 7 のような結果に なったものと思われる。

図 8 は, 粒子のガラス転移点分布が $30^{\circ} \mathrm{C}$ 単分散で ある場合に対する結果であり，母材単体に比べて，粒 子のガラス転移点近傍で $\tan \bar{\delta}$ は増加した. しかしな がら, 粒子と母材のガラス転移点の中間の温度範囲で

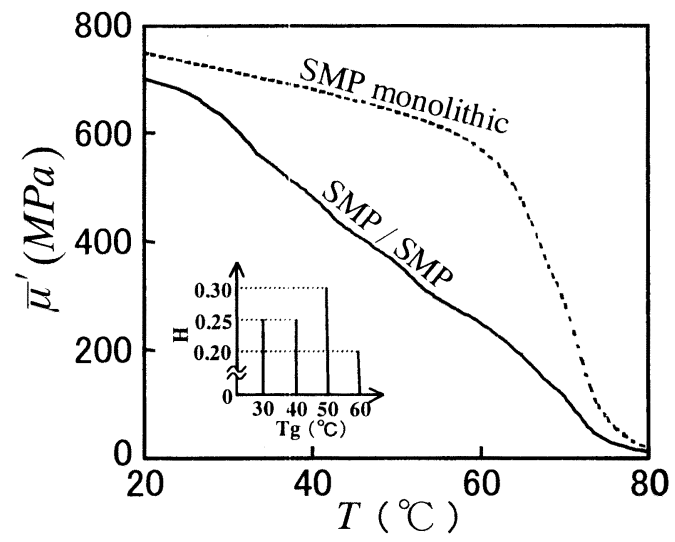

Fig. 9 Macroscopic shear modulus of the SMP Particle reinforced SMP Composite (4 Mode)

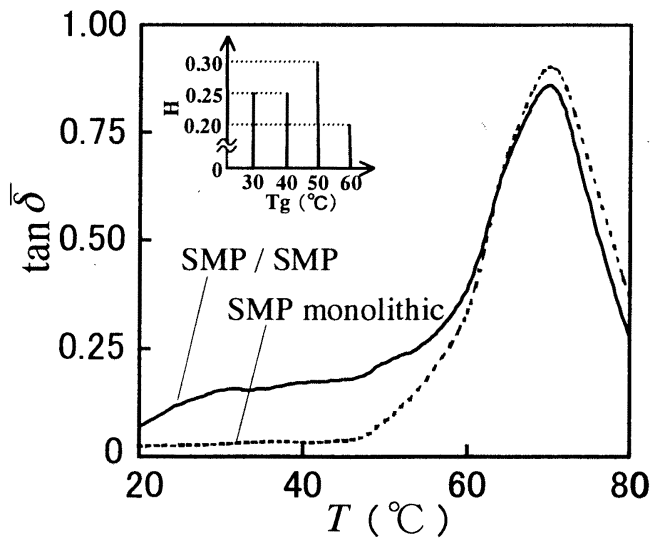

Fig. $10 \tan \bar{\delta}$ of the SMP Particle reinforced SMP Composite (4 Mode)
ある $50^{\circ} \mathrm{C}$ 近傍においては, 著しい増加は生じていな い.この点をさらに改善するために，さらに粒子のガ ラス転移点分布を工夫することにする。

$4 \cdot 2 \cdot 2$ 粒子のガラス転移点分布が 4 モード分布の 場合本解析で用いたSMPは，図 5 に示したよう にガラス転移点を挟んだ前後約 $10^{\circ} \mathrm{C}$ 温度幅で $\tan \delta$ が増加するという特徴を有している.このため, 図 8 においても, 粒子のガラス転移点 $30^{\circ} \mathrm{C}$ から $10^{\circ} \mathrm{C}$ 高い $40^{\circ} \mathrm{C}$ をで $\tan \delta$ が増加している. したがって, この点 を考慮すると, $10 \sim 15^{\circ} \mathrm{C}$ 刻みでガラス転移点が異なる 粒子を混入すればよいと思われる。

図 9 と図 10 は, 粒子のガラス転移点が $30^{\circ} \mathrm{C}$ から $10^{\circ} \mathrm{C}$ 刻みで $60^{\circ} \mathrm{C}$ まで 4 種類存在する 4 モード分布に 対する結果を示したものである，実線は複合材料の解 析結果を, 破線は母材単体のそれを示す。また, 図中 には粒子のガラス転移点 $T_{g}$ と確率密度 $H$ との関係 を示した分布も記載している．全粒子の体積含有率は 単分散の場合と同様に $50 \%$ を用いた。

図 9 より, 巨視的剛性率 $\bar{\mu}^{\prime}$ は, 4 モードガラス転移 点分布を用いた場合には, $25 \sim 75^{\circ} \mathrm{C}$ 温度範囲におい て, 温度の上昇に伴ってほほ直線的に単調減少する傾 向にあることがわかる.これは, 4 モード分布では母 材を含めて五つの温度で順にゴム状態へと遷移するた め, その一段ごとの変化量が小さくなることによって 生じたものと考えられる.

図 10 は $\tan \bar{\delta}$ の解析結果である. 図 10 より, $\tan \bar{\delta}$ は $50^{\circ} \mathrm{C}$ 近傍においても母材単体のそれより増加して おり, $20 \sim 80^{\circ} \mathrm{C}$ とう広い温度範囲で母材単体のそれ と同等か，それより大きくなっていることがわかる. したがって, この結果より, 粒子のガラス転移点分布

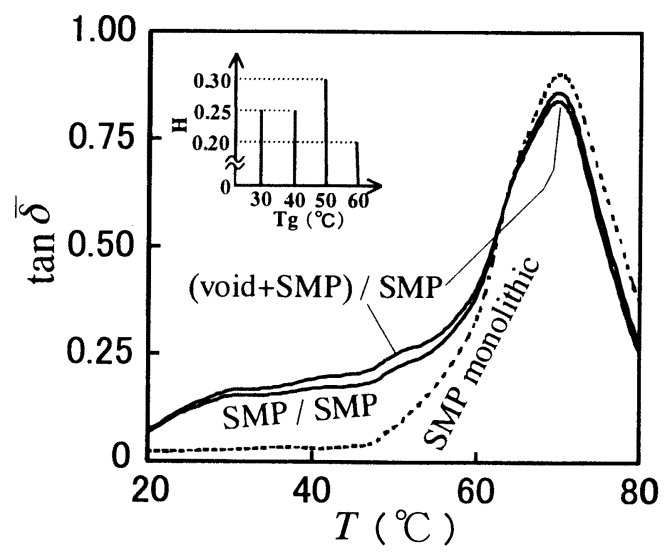

Fig. $11 \tan \bar{\delta}$ of the SMP Particle reinforced SMP Composite Containing Voids (4 Mode) 
を工夫することで, 制振特性が温度によらず一定であ る複合材料を設計できる可能性のあることがわかっ た。

$4 \cdot 2 \cdot 3$ 母材の剛性率を低下させた場合 次に, この巨視的タンジェントデルタをさらに増加させるこ とを検討する. $4 \cdot 2 \cdot 2$ 項で述べたように，巨視的剛性 率 $\bar{\mu}^{\prime}$ が減少すると $\tan \bar{\delta}$ は増加することから, 粒子の ガラス転移点分布は変えずに

図 11 は, 図 10 と同じ 4 モード分布で体積含有率 $50 \%$ SMP 粒子を含む複合材料に, 新たに体積含有 率 $20 \%$ の空孔を混入させた場合に対する $\tan \bar{\delta}$ の解 析結果を示したものである. 加えた空孔の剛性率と夕 ンジェントデルタはともに零とし, 形状は球形とし た。図中の (void+SMP)/SMPで示した実線がその 解析結果であり, SMP/SMP は図 10 の結果である. 図11より，さらに空孔を加えた場合には, $\tan \bar{\delta} は$ $70^{\circ} \mathrm{C}$ 近傍でわずかに減少しているものの $30 \sim 50^{\circ} \mathrm{C}$ 程 度の温度範囲で若干増加していることがわかる。した がって, 空孔を混入させて母材の剛性率を下げること でさらに $\tan \bar{\delta}$ を増加できることがわかった。

\section{5. 結 言}

本研究は広い温度範囲で良好な制振特性を有する高 分子系複合材料開発の可能性を探ることを目的とした ものであり, 種々のガラス転移点を有する SMP ポリ マ粒子を含む状態を想定し, これをマイクロメカニッ クスを用いてモデル化した.さらに, 具体的にポリマ 粒子のガラス転移点分布を与えることでモデルを解析 した結果, ガラス転移点分布に 4 モード分布を用いた 場合, 複合材料の巨視的タンジェントデルタは全温度
範囲で母材単体のそれに比べて向上することがわかっ た. したがって, ポリマ粒子のガラス転移点分布を適 切に与えることで, 広い温度範囲で制振特性が一定で ある高分子系複合材料を開発できる可能性があること がわかった．また，ポリマ粒子に加えてさらに空孔を 混入すると, 巨視的タンジェントデルタはさらに若干 増加することがわかった。

\section{文献}

（1）隆雅久・國尾武, 材料システム, 6 (1987), 21-48.

(2) Mura, T., Micromechanics of Defects in Solids, 2 nd revised ed., (1987), 1-587, Martinus Nijhoff Pub.

（3）若島健司，日本複合材料学会誌，2-4（1976），161-167.

（4）高橋清久, 日本複合材料学会誌, 8-2 (1982), 46-52.

(5) Takao, Y., Chou, T. W. and Taya, M., Trans. ASME, J. Appl. Mech.. 49 (1982), 536-541.

（6）北條正樹 - 高橋清久 - 林龍一，日本複合材料学会誌，9-2 (1983), 64-71.

(7) Benveniste, Y., Mcch. Matcr., 6 (1987), 147-157.

(8) Zhao, Y. H. and Weng, G. J., Trans. ASME, J. Appl. Mcch., 57 (1990), 158-167.

（9）荒木栄敏・斎藤憲司・加藤貴之 - 中原一郎, 機論, 61-588, A (1995), 1833-1840.

(10) Araki, S., Saito, K. and Kato, T., Theoret. Appl. Mech., 45 (1996), 67-78.

(11) Taya, M. and Seidel, E. D., Int. J. Eng. Sci., 19 (1981), 1083-1094.

（12）戸伏壽昭・林俊一, 機械の研究, 45-11 (1993), 1136-1140.

（13） 戸伏壽昭・林俊一, 機械の研究, 46-6 (1994), 646-652.

（14）山下浩儀・床井正護・荒木栄敏, 非圧縮性構成要素を含 む複合材料の巨視的剛性のマイクロメカニックス解析, 機講論, No. 02-05 (2002-10), 95-96.

(15) Mori. T. and Tanaka, K., Acta Met., 21 (1973), 571-574.

（16）戸伏壽昭・林俊一・小島伸一, 機論, 57-543, A (1991), 2760-2766.

（17）荒木栄敏・小野裕之・山田晴士・齊藤憲司, 機論, 67-659, A (2001), 1140-1147. 